\title{
Editorial: Property valuation - methods and models
}

\section{Property valuation research - make a contribution}

Welcome to this special themed issue on property valuation - methods and models. This was not an issue that was advertised as a special issue; it is a coincidental collection of papers submitted to a regular issue on the same topic. And that brings me to the central theme of this editorial, the importance of property valuation as a research topic and the ebb and flow of the subject over time. When Andrew Baum started this journal back in 1982, it was called "The Journal of Valuation," and all the papers were on the topic of practical applied valuations. This issue mirrors the same types of papers; articles that are directly relevant to the property valuation profession.

There is an appetite for such research and, looking at the download numbers for the journal, valuation papers have always in the top ten downloads each year every year. It is therefore surprising that when you look at the majority of authors of these papers, they are the same names that have been publishing on the topic for the last 20 or 30 years. So where are the young researchers on the topic? Where is the next generation of valuer academics and scribes? Who is going to carry the mantle going forward?

There is an opportunity for a young academic to take this topic and make it their own. Back in 1981, in the UK, there was no real literature on the topic apart from the short, albeit insightful, short briefings in the weekly Estates Gazette. The Journal of Valuation was the both the catalyst and outlet for a wealth of articles that helped the valuation profession establish itself as a learned vocation. And, with two name changes since, this is still true of the Journal of Property Investment \& Finance. But we need new young authors.

So if you want to establish a career for yourself and you want to build on the library of the literature that is now at your fingertips, do so. Make a contribution.

Nick French

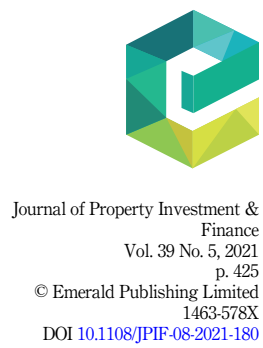

